\title{
THE BOAR FISH, CAPROS APER (L.), AS A POSSIBLE BIOLOGICAL INDICATOR OF WATER MOVEMENT
}

\author{
By L. H. N. Cooper, D.Sc., F.R.I.C. \\ Chemist at the Plymouth Laboratory
}

(Text-fig. I)

Capros aper (L.) is sporadic in its occurrence in the English Channel; for many years near Plymouth it has been scarce or absent. Between 3 June I948, when Capt. C. A. Hoodless began to keep exact records of all fish trawled by R.V. Sabella, and 29 June 1949 no Capros were taken by that ship. From 30 June 1949 to September I95I odd fish were trawled in the summer months, never more than three in a haul, and in October 195I two more fish were caught separately. Then on 30 October two hauls by R.V. Sabella about 5 miles south-west of the Eddystone brought up 1000 and 300 fish, followed by 50 on 13 November, 100 on Io December and 50 on 17 December. In the same area on I November M.F.V. Sula in two hauls caught 200 and 50 , a further 50 near Station E I on I4 November and 9 on I7 March 1952. All these catches were in hauls of $45-90 \mathrm{~min}$. duration. Single fish were taken by each ship in February 1952.

A hypothesis to explain the introduction of a considerable fresh stock of Capros into the English Channel late in the year has been developed from an earlier hypothesis (Cooper, 1952 a) concerning 'submarine eagres' in canyons in the continental slope.

On a number of occasions between July and October inclusive the postlarval stages of Capros have been recorded by Russell (1930-47) and Corbin (I948-5I) from the $2 \mathrm{~m}$. ring-trawl catches taken weekly 2 miles east of the Eddystone. In all years in which young Capros occurred, except 1937, the species of the siphonophore, Muggiaea, occurring at about the same time was $M$. kochi and not M. atlantica. M. kochi was the species present (Corbin, private communication) on 24 October I95I at International Station EI, a few miles from the position where the large hauls were made a few days later. There are reasons, as yet unpublished, for suspecting that $M$. kochi in the English Channel may indicate deeper water brought up over the continental slope lying to the south-west. These events therefore suggested that Capros might also indicate water from the continental slope.

In the Plymouth aquarium Capros, by means of gentle fin movements, may remain poised almost stationary in the water or make slow excursions around 


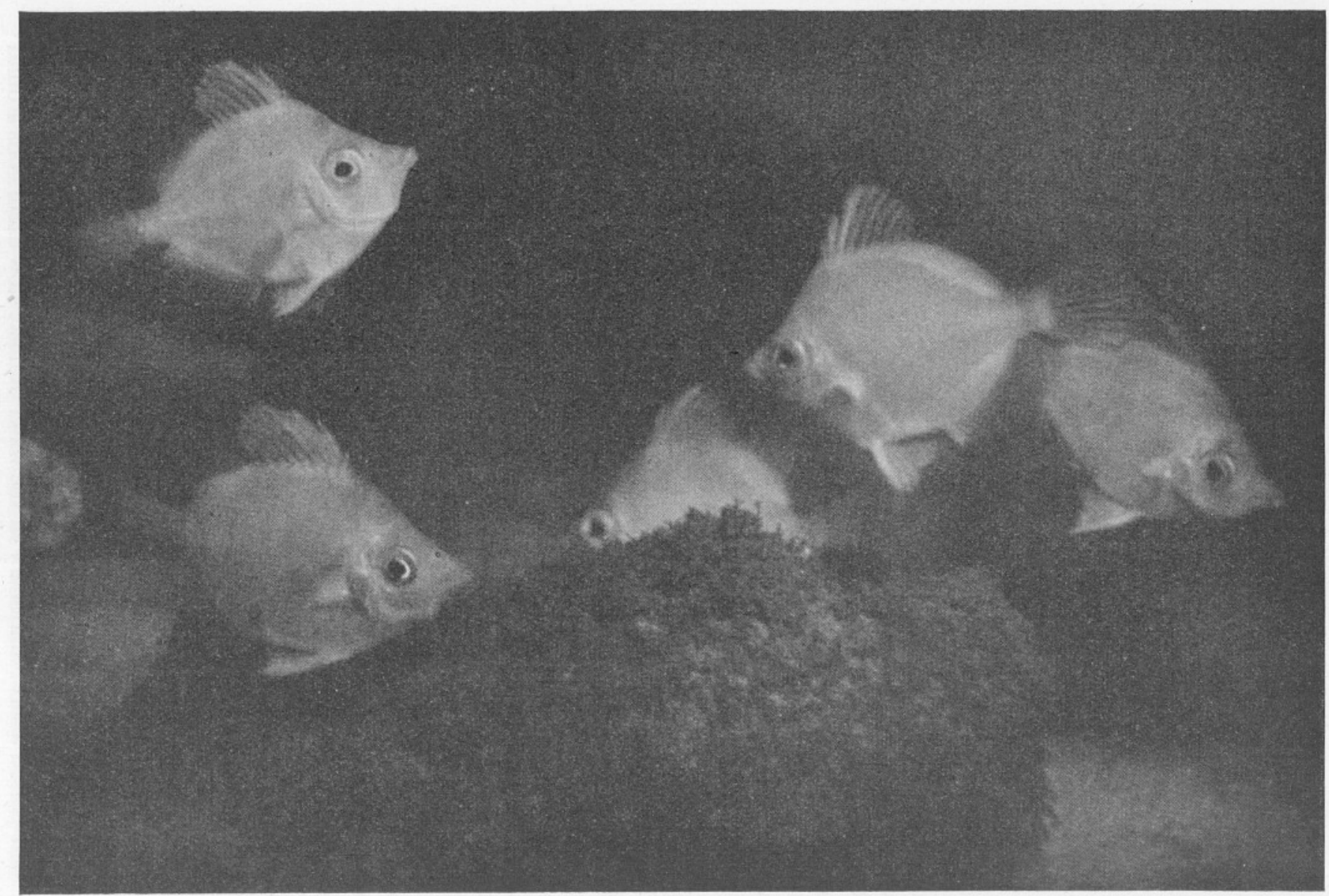

Fig. I. Capros aper in the Plymouth Aquarium. Photograph by D. P. Wilson. Two-thirds natural size. 
the tank. Occasionally it may make short random darts through the water. Since it does not appear the sort of fish to make far-reaching migrations by swimming, the illusion of migration may be due to travel from some distant source of the water mass in which it occurs. If so it might be of value as a biological indicator of water movement.

Records of its distribution have been summarized by Cornish (I868), Gatcombe (1879) and Legendre (1934). The latter took eighteen examples from the stomachs of germon or white tunny (Germo alalunga) caught in the Bay of Biscay north-west of Concarneau. Capros has often been found in the stomachs of tunny. Apart from records near Plymouth or off Cornwall, all others are near to the western Eurōpean or Mediterranean continental slopes. All authorities agree on a distribution epitomized by Holt \& Calderwood (I895) who said that 'it is known to frequent rather deep water, although in the neighbourhood of Plymouth it is tolerably abundant in depths of less than 30 fathoms during summer months'. In I879, Gatcombe was told that within a few years Capros had become a pest, so much so that trawlers had been obliged to change their fishing grounds to avoid them. So great was the weight of the fish that the fishermen had to cut large holes in their nets to let them escape.

Collett (I896) stated that it occurs along coasts in great numbers only after storms. He was writing mainly of the Mediterranean where continental shelves are narrow and either 'submarine eagres' or 'capsizing of water masses' would introduce Capros directly into coastal waters.

Le Danois (I9I3) said that it is a deep-water fish and that only accidentally does it rise to the shallow banks of the English Channel. Later (I943, p. I42) he suggested that the group containing Capros has evolved around coral reefs. In his constructive broad survey of the fauna of western European waters he (I948, p. 278) classes $C$. aper as an inhabitant of the 'bordure continentale' and Atlantic slope and associated there with the coralline facies. The corals he divides into yellow and white (or flesh pink, rose chair). According to Le Danois the yellow coral, unlike the white, does not thrive in mud and prefers hard steep rocks. It is most often found on parts of the Atlantic Slope which are tourmenté et chaotique. It would be the species of coral most likely to occur on the steep sides of submarine canyons. This association should mean that Capros is indigenous in submarine canyons encrusted with yellow coral. In clear well-illuminated water the yellow or straw colour of Capros should provide camouflage amongst such yellow coral, but it probably has little value in the almost dark waters below $200 \mathrm{~m}$. depth.

However, Day (i880) described fish which when first received in the Westminster aquarium from Mevagissey were of a rich red hue changing in the course of a few days to straw colour. Their colouring may be banded or plain. Evidently, if it so wished, Capros could adapt itself to match either of the coralline environments described by Le Danois, if sufficiently illuminated. 
Our present interest will be centred on the population of Capros which may occur associated with yellow coral in the upper and narrower parts of submarine canyons between about 200 and $500 \mathrm{~m}$. in depth.

A hypothetical submarine eagre, arising from vertical oscillations in stratified water following on-slope strong winds, has been suggested (Cooper, I $952 a$ ) as running up a submarine canyon like a bore or eagre in the Rivers Severn or Trent. In the upper, more constricted, part of the canyon this submarine eagre is considered likely to become quite violent, sufficiently so to dislodge Capros from its environment against the coral encrusted walls, to which the fish would be unable to return. It is scarcely credible that the momentum of such an eagre could carry the water and the fish in it the 200 miles from the continental slope to the neighbourhood of the Eddystone nor is that necessary. It is necessary only to believe that the eagre projects the water sufficiently far on to the continental shelf for it to get caught up in the general cyclonic circulation of the Celtic Sea. The eagre would inject a limited mass, a 'bubble' or 'eagre spurt' of canyon water into shelf water which could have quite different properties but which, none the less, would become effectively labelled by the considerable population of Capros.

To be of value as a biological indicator Capros would need to be exceedingly abundant in its coralline home. However, it is not postulated that there is always a dependable uniform stock available to colonize submarine eagres. The continental slope would seem likely to be an exacting environment for species largely restricted to it, so that the population of Capros against the slope may fluctuate widely.

A canyon wall swept clean of Capros by a submarine eagre would be slowly re-colonized either by adults moving in from neighbouring less dissected areas of the slope, including the muddy areas inhabited by 'white coral', or by metamorphosis in the right place of larvae spawned from such areas. There may be a difference in age composition of Capros populations in submarine canyons and in the Celtic Sea and English Channel, on the one hand, and over the muddy white-coralline areas on the other.

A submarine eagre would introduce on to the continental shelf a compact population of Capros, but the water introduced with the fish might be of two kinds. An eagre spurt is visualized as having a compound structure. After a persistent strong on-slope wind a homogeneous water-mass is likely to be present, not only within submarine canyons to several hundred metres depth, but also for some miles inward over the continental shelf. As the wind dies down the water in the canyon may oscillate. The upper part which would sweep out the stock of Capros on to the shelf need not be distinguishable from the neighbouring shelf water. The event could not be followed by measurements of chemical properties or temperature but only by current meters or biological indicators. However, towards the end of a large and deep oscillation, when the canyon walls have been swept clean of Capros, deeper water 
of markedly different properties and richer in nutrients should follow. The result may be compared with a comet, the head of the eagre spurt being characterized only by Capros and any accompanying biological indicators, the tail containing few Capros but distinguishable chemically.

The subsequent history of an eagre spurt on the continental shelf would depend on the general circulation, tides, bottom topography and weather. When, as often, the general circulation is cyclonic, Capros from the southern edge of the Celtic Sea would be carried towards Ushant, the English Channel and Land's End.

Sometimes, but not always, eagre-spurt water would be slightly heavier than water over the shelf where it would tend to fill the troughs in the sea bed. There Capros would be expected to be trawled in large numbers more often in the troughs than on the banks. Such a distribution would be due to the topography and not to the nature of the sea-bed.

All currents are zero in immediate contact with the bottom and increase in strength upwards and the strongest currents are tidal. According to van Veen's formula (1936) the current at $4 \mathrm{~m}$. off the bottom will be about twice that at Io $\mathrm{cm}$. so that tidal currents will tend to spread any dense population of truly demersal fish. In the southern Celtic Sea the major and minor axes of the tidal ellipses are almost equal so that there a circular shoal of fish would, as it spreads, remain almost circular. But in the English and Bristol Channels, the tidal streaming is almost linear, flood and ebb currents each flowing in almost the same directions for several hours. The major axis of the tidal ellipse much exceeds the minor. In these waters a dense demersal shoal will not spread radially as in the Celtic Sea but into an elongated band. Strongly swimming fish, such as the gadoids, may. well choose to reform a compact shoal if this better suits their way of life but it is unlikely that Capros could do so. If the present hypothesis is correct shoals of Capros in the western English Channel, but not in the Celtic Sea, are likely to occur as elongated bands, aligned along the major axis of the tidal ellipse.

This theorem is worth investigation for a practical reason. All strictly demersal shoaling fish are likely to respond to this effect of the tide in some degree. If therefore a trawler detects on its echo-sounder a shoal of fish near the bottom, it is likely in the English Channel to make better catches by towing its trawl in or against the direction of the main tidal stream than by towing across it.

An eagre spurt containing Capros in numbers will be subject not only to spreading due to differential bottom currents but to attrition due to bottom friction of all kinds. Odd fish would become distributed over a much wider area than that of the eagre spurt which may be identified only while the population remains dense.

Submarine eagres can arise only in stratified water and stratification over the continental slope, as elsewhere, is most strongly developed in summer. 
Consequently, only then would shoals of Capros be injected on to the continental shelf to arrive off Plymouth some weeks later. Again, in shallow homogeneous water wind causes vertical and lateral mixing right to the bottom. In winter strong winds should disperse shoals of Capros. Although beneath a thermocline, strong winds may produce more mixing than has been hitherto realized (Mortimer, I952), nevertheless, the forces tending to disrupt shoals will be much less in summer.

Table I. Strong Winds in the Celtic Sea, September i95I

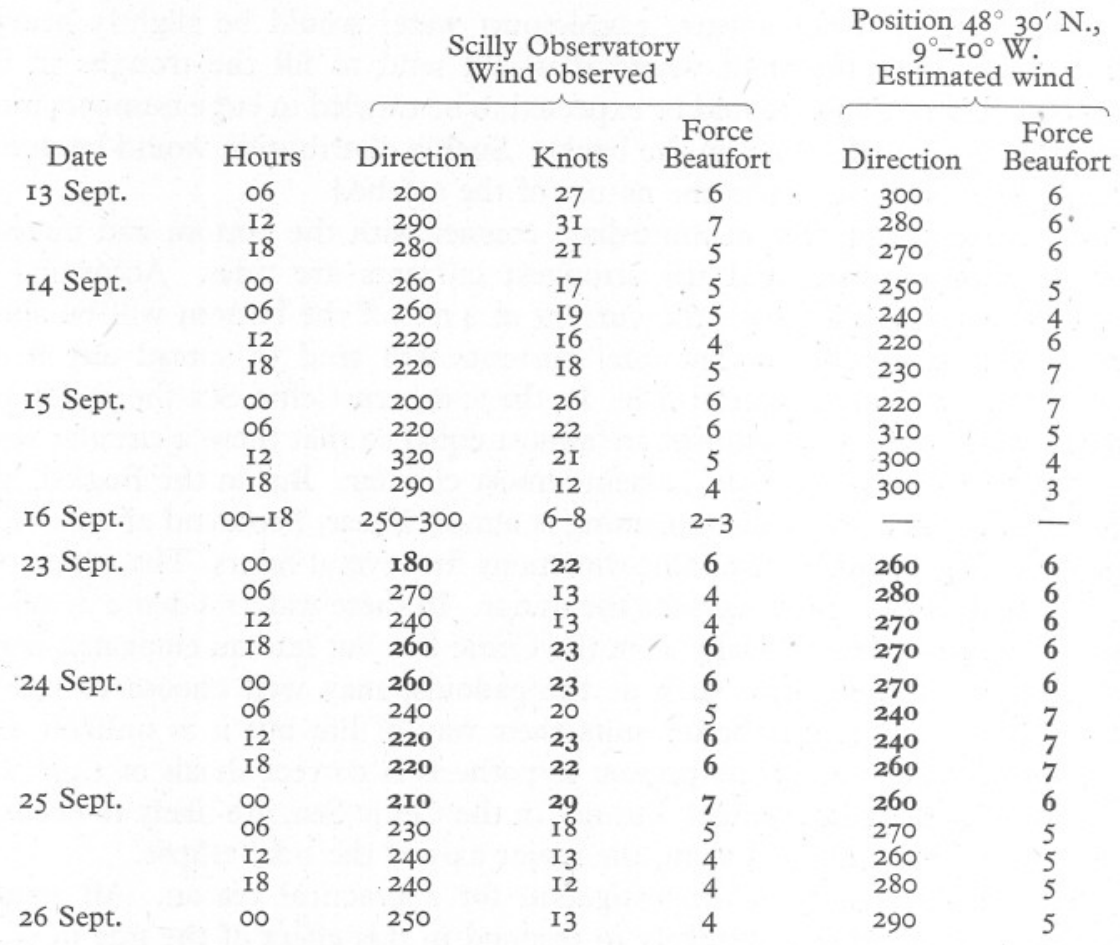

There is a critical wind speed at about $7 \mathrm{~m}$./sec. (I4 knots, Beaufort Force 4 ) (Rossby \& Montgomery, I935; Munk, 1947). Above this speed the effect of wind becomes 'hydrodynamically rough'. Only such winds can get hold of the water sufficiently to produce the conditions which must precede submarine eagre formation. The effect of wind of Beaufort Force 4 will be trivial.

A minimum Force 6-7 (22-33 knots; II $-\mathrm{I} 7 \mathrm{~m}$./ $/ \mathrm{sec}$.) was visualized as necessary to produce the cushion of light water against the slope, the upward swing of which would produce a submarine eagre when the wind dropped. Winds of this strength were recorded on I3, I5, 23 and 24 September I95I (Table I). 
The nearest British Meteorological Station is at Scilly (St Mary's) about I50 miles from the area where information is required. Every $6 \mathrm{hr}$. in the Daily Weather Reports the anemometer readings there are reported for direction and strength in knots. These exact records have been extracted. From the further reports from merchant and weather ships (including the French vessels at $45^{\circ} \mathrm{N}$., I $6^{\circ} \mathrm{W}$.) and the $6 \mathrm{hr}$. synoptic isobaric charts, assessments of wind direction and speed in knots at $48^{\circ} 30^{\prime} \mathrm{N} ., 9-10^{\circ} \mathrm{W}$. have been made. They are printed in Table I as Beaufort numbers which correspond better to their probable accuracy.

In submarine canyons facing into the wind, submarine eagres could have been created on 14,15 and 25 September' when the strong winds dropped. The lull of about I $2 \mathrm{hr}$. on I4 September may not have been long enough to be effective while any dense shoal of fish ejected on to the shelf then or on I5 September would probably have been dispersed by the strong wind on 23 and 24 September. It is suggested that on the following day, 25 September, when the wind dropped to 13 knots at Scilly and did not exceed 18 or perhaps 20 knots near the slope, an eagre spurt was injected on to the continental shelf from a submarine canyon and that this brought up the population of Capros which was found near the Eddystone on 30 October and subsequently. Such spurts were possible in a number of the canyons depicted by Beaugé (I934).

The continental slope concerned runs from south-east to north-west, and the axes of most of the reputed canyons point south-west or south. In these, south-westerly or southerly winds should be most favourable for creating eagres. However, one of the largest canyons at $48^{\circ} 22^{\prime} \mathrm{N} ., 9^{\circ} 30^{\prime} \mathrm{W}$., named by the French Fisheries Department 'la Machoire du Sud' has an almost straight axis pointing west by south. Its southern wall has been defined by H.M.S. Dalrymple also. In this canyon, and in this alone, westerly winds could create considerable submarine eagres. On 25 September a large eagre was more likely to occur there than in any other canyon. The winds most likely to have been responsible for the eagre spurt which brought in the Capros shoal are printed in heavy type.

Once this was achieved quiet weather was needed to allow the shoal of Capros to reach the neighbourhood of the Eddystone intact. For the remaining 5 days of September force- 4 winds were consistently recorded at Scilly. Thence, until 30 October, of 120 records of wind at Mount Batten, Plymouth, only I2 were in the range II-I6 knots (force 4) and but one reached 17 knots. Such light winds would have little power to disperse an eagre spurt travelling up-Channel. The meteorological records were therefore precisely what the theory demands. If this view is correct, the shoal of Capros was carried about 200 miles in the eagre spurt in 35 days, or about 6 sea miles per day.

Water containing Capros in an eagre spurt may be heterogeneous. Only if the water can be sampled in the middle of the shoal could distinctive 
hydrographical results be expected. Trawling does not generally enable one to know exactly where such a shoal was placed. Even if the centre of the shoal could be found, a high salinity characteristic of slope water is to be expected only under very favourable conditions. Let us consider an unmixed eagre spurt, fresh from a canyon, containing 10,000 Capros per standard trawl haul and having a salinity of $35.6 \%$ and a total phosphorus content of $0.9 \mu \mathrm{g}$.-atom $/ 1$. Let us consider its admixture with enveloping water containing no Capros, a salinity of $35.20 \%$ and total phosphorus amounting to $0.5 \mu \mathrm{g}$.-atom $/ 1$. The mixed waters would have the properties set out in Table II.

In October and November I95I there was no change in the chemical properties of the water at the nearby station E I which could be associated with the incursion of Capros. Thus, if the hypothesis can be proved, Capros aper would provide a far more sensitive indicator of the presence of continental slope water near Plymouth than would any chemical determination.

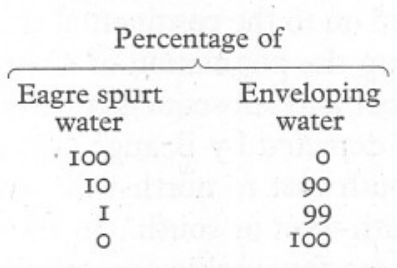

\section{TABLE II}
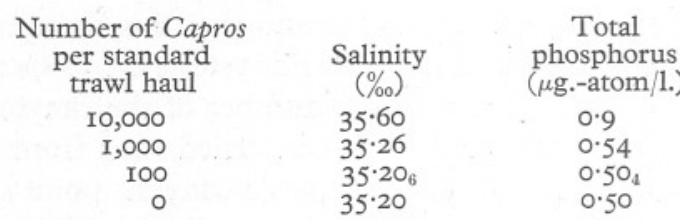

A criticism may be made that a density of fish in an eagre spurt as high as that assumed in Table II is improbable since, for lack of food, deep-water fish are rarely in sufficiently dense concentration. This may be especially true of a species that remains in much the same place. What would it eat? The rain of food from above would support a certain number but surely not so many? In the open ocean this criticism would be pertinent, but further investigation may show that it is not true against a continental slope where food may arrive by means other than 'raining down'. There is abundant evidence (inter alia Cooper, 1952 $a$, fig. 3, Station 5I; and $1952 b$ ) that in winter vertical homogeneity of water against the slope, which must be due to vertical mixing, extends at least 3 to 5 times deeper than it does in the open ocean to the westward. This vertical homogeneity is a fact and not dependent on the hypotheses of cascading, capsizing and submarine eagres which have been erected to explain it. The vertical movement or mixing of the water, whatever its cause, will carry downwards some of the organisms which cannot swim. The population of these in the $200-400 \mathrm{~m}$. strata against the slope is likely to be comparable with that in the surface layers. Again, there are numbers of strongly swimming vertical migrants near the slope, such as Sagitta serratodentata, which feed near the surface at night and make diurnal vertical migrations to several hundred metres depth. In the ocean against 
a continental slope-and only there-reserves of food for fish comparable with those over continental shelves are likely to be present at considerable depths. Probably, therefore, dense populations of fish at depth in these submarine canyons may find adequate food at any season, and abounding food during cascading or after southerly storms. On this view the postulated catch of I0,000 Capros thrown up by a submarine eagre and caught in a standard trawl haul does not seem so unreasonable.

Since trawls and dredges are very inefficient instruments to sample fish sheltering against the rugged walls of a submarine canyon, the only hope of obtaining evidence of abundance in such a place would seem to be with an under-water camera, protected by a cage and triggered to take a photograph when the cage strikes a canyon wall.

It would be unreasonable to assert that eagre spurts similar to that here discussed did not occur in the nineteen-thirties. If they occurred they brought few Capros. Consequently, the present hypothesis is acceptable only if we further assume that the stock of Capros over the continental slope underwent a decrease in numbers comparable with that undergone by many fish and invertebrates near Plymouth at the same time. Catastrophes to adults or eggs and larvae due to excessively violent capsizing might provide an explanation of short-period changes but are unattractive to explain longperiod fluctuations. It is more probable that the water of the Atlantic Ocean bathing the continental slope has been subject to vicissitudes similar to those in the English Channel. We should then have to seek an understanding of local events in terms of changes in the fundamental circulation of the Atlantic Ocean.

Within the English Channel Capros would find conditions resembling its postulated indigenous home only on rocky declivities from which tidal currents and breaking seas would tend to detach it. If a stock of the fish were carried into the Hurd Deep, there against the steep walls it might find food and shelter and thrive for a while. The Hurd Deep would then provide a centre of dissemination of Capros eggs. Again, a passing shoal might attempt a lodgement amongst the rocks of the Eddystone where they may live undetected for some while. Eggs spawned there would be sampled at the standard young-fish-trawl station 2 miles to the eastward. In similar vein, Couch (I863) mentioned that a Penzance trawler in July I844 in a few days caught about 200 close into the Runnelstone. He says: 'These fish may always be found within half a mile of this well-known rock, where they are probably induced to assemble by congenial food; but they are scarce, or not to be found beyond that distance.' Care would be needed that such local and possibly temporary populations do not upset a picture dependent on recruitment from the south-west. 


\section{CORROBORATION}

Mr J. Taylor and Mr L. Cunnington, skipper and mate of M.F.V. Fago, later reported that between 25 June and 3 July I 947 near the Lizard they took . an exceptionally large haul of Capros. The gear for heaving the cod-end in board was pulled down several times. The trawl in use was brand new, otherwise it would not have stood up to the great weight without splitting. Buried amongst the Capros and scarcely visible were twenty-two baskets of hake.

After I May the only winds as strong as Beaufort Force 6-7 occurred on 4 and 6 June (Table III) and these were westerly. In La Machoire du Sud, and in this canyon only, could these winds have created the considerable submarine eagre on 7 June believed to have introduced the dense shoal of

Table III. Strong Winds in the Celtic Sea, May-June 1947

\begin{tabular}{|c|c|c|c|c|c|}
\hline \multirow[b]{2}{*}{ Date } & \multirow[b]{2}{*}{$\begin{array}{l}\text { Hours } \\
\text { (G.M.T) }\end{array}$} & \multicolumn{2}{|c|}{$\begin{array}{l}\text { Scilly Observatory } \\
\text { Wind observed }\end{array}$} & \multicolumn{2}{|c|}{$\begin{array}{c}\text { Position } 48^{\circ} 30^{\prime} \mathrm{N} ., 9^{\circ}-10^{\circ} \mathrm{W} . \\
\text { Estimated wind }{ }^{\star}\end{array}$} \\
\hline & & Direction & $\begin{array}{l}\text { Force } \\
\text { Beaufort }\end{array}$ & Direction & $\begin{array}{l}\text { Force } \\
\text { Beaufort }\end{array}$ \\
\hline 4 June & 18 & W.N.W. & 6 & W.'N. & 6 \\
\hline 6 June & $\begin{array}{l}00 \\
06 \\
12 \\
18\end{array}$ & $\begin{array}{c}\text { W.'S. } \\
\text { W. } \\
\text { w.'N. } \\
\text { w.S.w. }\end{array}$ & $\begin{array}{l}6 \\
7 \\
6 \\
5\end{array}$ & $\begin{array}{l}\text { W. } \\
\text { w.N.w. } \\
\text { W. } \\
\text { w.S.w. }\end{array}$ & $\begin{array}{c}6 \\
6 \text { or } 7 \\
6 \\
4\end{array}$ \\
\hline 7 June & $\infty$ & S.W.'S. & 4 & w.S.W. & 4 \\
\hline
\end{tabular}

* Assessed from observations by British Observing Ships in the area between $45^{\circ}$ and $50^{\circ} \mathrm{N}$., and between $7^{\circ}$ and $13^{\circ} \mathrm{W}$., supplied by the Marine Superintendent, Meteorological Office, Harrow.

Capros. The shoal would have been carried by the current about 200 miles in 18-26 days at an average speed of 7-II miles a day. The evidence is scarcely strong enough to assert that the associated hake, a slope fish, came from the same source.

There appears to be a neighbouring canyon, La Machoire du Nord, which for much of its length runs west-south-west but in its upper and shallower course it turns for 5 miles to face south by west. Creation of eagres there in westerly winds is less likely.

We now have two events to support the real existence of submarine eagres, and both times La Machoire du Sud canyon is indicated as the site. Of necessity the argument has had to be based on the coincidence of large catches of Capros with the occurrence a few weeks earlier over the continental slope of westerly or south-westerly winds of Beaufort Force 6-7. These are prevailing winds so that the coincidences may be due to pure chance. Whereas one failure to find a fit will kill the hypothesis, certainty will come only by accumulating many such coincidences. The author would therefore appreciate news from fishing skippers of the time, position and quantity of all catches 
of Capros (zulus) exceeding, say, I000, together with information as to the gear used and the duration of the haul.

Evidence for the hypothesis of submarine eagres could be sought by trawling at the right time on the fine sandy bottom which exists at $48^{\circ} 23^{\prime} \mathrm{N}$, $9^{\circ} 20^{\prime}$ W., inshore of the heading of La Machoire du Sud. Some hours after strong winds (Beaufort Force 6-7) from between south-west and west have died down, Capros in very large numbers may there be introduced by an eagre from the canyon.

The writer is indebted to Mr A. D. Mattacola, who drew attention to the notable hauls of Capros and has helped in many ways and to Lieut.-Cmdr. C. A. Hoodless, D.S.C., R.N.R., for his exact records of catches.

\section{SUMMARY}

Notable catches of boar fish (Capros aper) were taken near the Eddystone on 30 October and in early November 195I. From what is known of the distribution of boar fish and from the hypothesis on the genesis of 'submarine eagres' in canyons on the continental slope, a further hypothesis has been derived to explain this occurrence. It is suggested that strong west to southwesterly winds on 24 September created conditions to produce a submarine eagre the following day, and that this swept a shoal of boar fish from the yellow-coral encrusted walls of a submarine canyon in the southern edge of the Celtic Sea on to the continental shelf. Thence during quiet weather the shoal was carried by currents to the neighbourhood of the Eddystone at about 6 miles a day. Further deductions which lead to means of checking the present hypotheses have been drawn.

An exceedingly large catch of Capros taken by M.F.V. Fago in the summer of 1947 is attributed to a shoal ejected on 7 June in a submarine eagre from a large canyon at $48^{\circ} 22^{\prime} \mathrm{N} ., 9^{\circ} 30^{\prime} \mathrm{W}$.

\section{REFERENCES}

BeAugÉ, L., 1934. Entrée ouest de la Manche. Carte 2, Haut fond du Président Théodore Tissier. (Carte préliminaire-Août 1934.) Paris: Office des Pêches Maritimes.

Collett, R., I896. Poissons provenant des campagnes du yacht l'Hirondelle (1885-1888). Res. Camp. Sci. Albert Ier, Prince de Monaco, Fasc. x, pp. I-I98.

COOPER, L. H. N., I952 $a$. Processes of enrichment of surface water with nutrients due to strong winds blowing on to a continental slope. Fourn. Mar. Biol. Assoc., Vol. 30, pp. 453-64.

- $1952 b$. The physical and chemical oceanography of the waters bathing the continental slope of the Celtic Sea. Fourn. Mar. Biol. Assoc., Vol. 30, pp. 465-5 Io.

Couch, J., I863. A history of the fishes of the British Islands. Vol. II. London.

CoRBIN, P. G., I948-5I. On the seasonal abundance of young fish. IX, X and XI. The years 1947, I948 and 1949. Fourn. Mar. Biol. Assoc., Vol. 27, pp. 718-22; Vol. 28, pp. 707-I2; Vol. 30, pp. 27I-5. 
CoRnish, T., I868. Boar-fish near Penzance, and at Whitsand Bay, Land's End. Zoologist, Ser. 2, Vol. 3, p. I222.

DAY, F., I880. On the change of colour in the boar-fish and the growth of the turbot. Zoologist, Ser. 3, Vol. 4, pp. 383-8.

Gatсомве, J., I879. Boarfish off Plymouth. Zoologist, Ser. 3, Vol. 3, pp. 429, 46I-2.

HolT, E. W. L. \& CALDERWOod, W. L., I895. Survey of fishing grounds, West Coast of Ireland, I890-9I. Report on the rarer fishes. Sci. Trans. Roy. Dublin Soc., Ser. 2, Vol. 5, pp. 359-524.

LE DANOIS, E., I9I3. Contribution à l'étude systématique et biologique des poissons de la Manche occidentale. Ann. Inst. Océanographique, Paris, T. 5, fasc. 5, pp. I-2I4.

_ I943. Océanographie, biologie marine et pêches. Remarques ichthyologiques. Rev. Trav. Pêches Marit., T. I3, pp. 54-I75.

- 1948. Les profondeurs de la mer: Paris. $303 \mathrm{pp.}$

LEGENDRE, R., I934. La faune pélagique de 1'Atlantique, au large du Golfe de Gascogne, recueillie dans des estomacs des Germons. I. Ann. Inst Océanographique, T. 14, pp. 246-4I8.

MoRTIMER, C. H., I952. Water movements in lakes during summer stratification; evidence from the distribution of temperature in Windermere. Phil. Trans. Roy. Soc. B, Vol. 236, pp. 355-404.

Munk, W. H., I947. A critical wind speed for air-sea boundary processes. Fourn. Mar. Res., Vol. 6, pp. 203-18.

Rossby, G. G. \& Montgomery, R. B., I935. The layer of frictional influence in wind and ocean currents. Pap. Phys. Oceanog., Vol. 3, Pt. 3, pp. I-IOI.

RUSSELL, F. S., I930-47. On the seasonal abundance of young fish. I-VIII. Fourn. Mar. Biol. Assoc., Vol. 16, pp. 707-22; Vol. 20, pp. 147-79 and pp. 595-604; Vol. 2I, pp. 679-86; Vol. 22, pp. 493-500; Vol. 23, pp. 38I-6; Vol. 24, pp. 265-70; Vol. 26, pp. 605-8.

van VeEn, J., I936. Onderzoekingen in de Hoofden. The Hague. 252 pp. 